\title{
血液幹細胞の臨床
}

\author{
自治医科大学内科 \\ 高久 史麿

\section{GLINICAL SIGNIFICANCE OF HEMATOPOIETIC STEM CELLS} \\ Fumimaro TAKAKU, MD \\ Department of Medicine, Jichi Medical School
}

\begin{abstract}
骤要 血液細胞の分化特に造血幹細胞に関する研究は近年著しい進歩をとげ，その知識は各種血液疾 患の病態の理解の上で炊第に不可欠なるのになつてきている. 本文におい、ては造血幹紐胞の分化の基 礎的な問題について简単に紹介すると同時に，この練胞の有している病態生理学的並びに臨床的意義 に関して概説を加えたなおお本文の記載にさいしては幹細胞に関する臨床的な研究をひろくとりあ げ，現在迄に発表されたこの問題に関する多くの研究者の成果を紹介すると共に，その中に著者らの グループが従来から行なつてきた幹細胞についての臨床的な研究の結果を随時とりいれた 赤血球系 科胞の異常では，再生不良性貧血を中心とする骨䯣の低形成に上る省血症，或いは真性多血症の様な 赤血球産生の增加の機序に造血幹細胞の巽常が密接に関与している事が明らかになつている. 一方, 顆粒球系細胞に和いても白血病が造血幹細胞のレベルの異常である事が様々な研究の結果明らかにな つたささらに從来前白血病状態とよんでいる各種血液疾患においても，幹細胞に質的或いは量的な異 常が存在し, その異常が以後の白血病の進展滵接に関連する事が明らかになつている. 造血幹細胞 は，各種血夜疾患の病態生理に深い関連を有しておう，その意味では幹細胞異常と呼ばれるべき一群 の疾患群があると考号られる. 幹細胞は又再生不良性貧血に対するアンドロゲン療法, 或いは再生不 良性貧血や白血病に対する骨䯣移植に理論的な根起を与えるものである.
\end{abstract}

\section{I. はじめに}

造血幹細胞 (hematopoietic stem cell) を中心 とする血球の分化に関する基礎的，並びに臨床的 研究は近年著しい進歩を遂げ，造血幹細胞とその 分化に関する基礎的な知識を有していなければ， 各種病的状態における血球産生の変動の機序を理 解する事が，困難になつてきているといつても過 言でないのが現状である。この問題に関する研究 は現在むな括活発以進められ，新しい知見が次々 に見出されている，本文では血液幹細胞の臨床的 意義に関して概説するが，乙の前に幹細胞とその 分化に関する基礎的な問題を簡単に紹介したい。

\section{II. 造血幹細胞とその分化}

血球の分化に関する研究の初期には，一種類の 造血幹細胞のみが存在すると推定された事があつ た，しかし，その後この問題に関する基礎的な研 究の進展と共に, 幹細胞自体にもいくつかの分化 の段階のあののあることが判明し，現在では図 1 に示す如くリンか゚球系並びに骨髄系細胞の両方に 共通な全能性幹細胞（totipotential stem cell） か らリンパ球系幹細胞と骨随系幹細胞が，又リンパ 球系幹細胞からはT cell系およびB cell系のリン 弪球が，骨䯣系幹細胞からはおの打の赤血球系， 顆粒球一マクロファージ系，好酸球系並びに巨核 


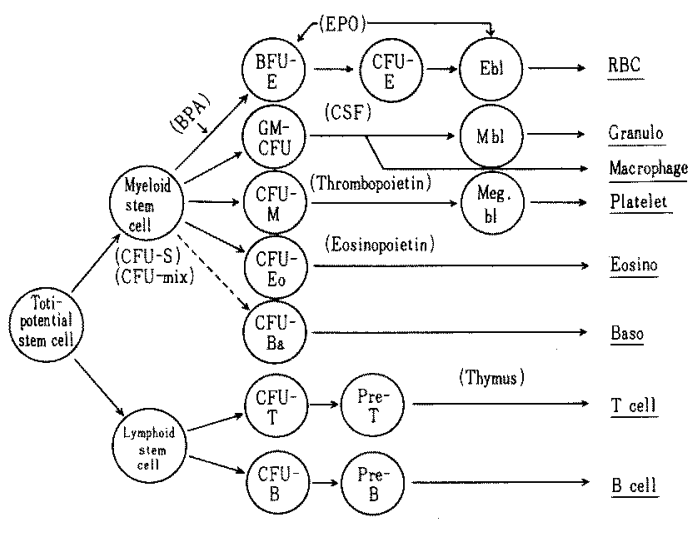

EPO : erythropoietin

$\mathrm{BFU}$ : burst forming unit

CFU : colony forming unit

BPA : burst promoting activity

CSF : colong stimulating factor

$\mathrm{E}$ : erythroid

S: spleen

GM : granulocyte macrophage

M : megakaryocyte

Eo: eosinophil

$\mathrm{Ba}$ : basophil

因 1，造血細胞の分化

球一血小板系の 幹細胞が分化すること文 -5)，赤血 球系幹細胞の中にもいくつかの分化の段階のもの がある゙ ことなどが明らかにされている，最近 になつて，さらに好塩基球尚骨髄から由来する事 が動物実験によつて証明されている は好塩基球数の著しい増加を示した白血病症例の 末梢血を培盖することによつて好塩基球コロニー をつくることに成功して扣り ${ }^{11)}$ ，肥満細胞一好塩 基球系細胞む個有の幹細胞を骨䯣中に有すると考 卉られる。

血液幹細胞の存在を最初以証明したのはTill \& McCullochである。彼らは大量照射マウスに同種 マウスの骨髄細胞を移植し，移植されたマウスの 脾臟中に多数のコロニーが見出されること，しか むおのおののコロニ一は赤血球系細胞，顆粒球系 細胞，巨核球系細胞，並びにこれらの細胞の混合 したコロニーから成ること，したがつて個々のコ 口二ーが各系統の血球に分化しらる多能性幹細胞 から由来することを明らかにしだ 。このコロこ 一のもとになる細胞は，その测定方法からcolony forming unit in spleen (CFU-S) と呼ばれ, 現在 でも幹細胞を同定する有力な万法の一つとなつて いる.しかし最近では幹細胞の同定はもつばら 造血組織の in vitro 組織培養によつて行なわれ るようになり，培養の結果生じた赤芽球，顆粒

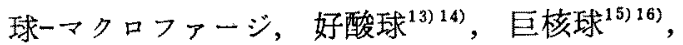
$\mathrm{T}$ cell ${ }^{17)}{ }^{18)}$ ，蛙よび B cell ${ }^{19)}$ からなるコロニーの もとになる各系統の幹細胞を図 1 亿示す如く、お の括の赤血球系 (BFU-E, CFU-E) - 顆粒球一 クロファージ系 (GM-CFU) ${ }^{1)}$ ・好酸球系 (CFUEo) • 巨核球系 (CFU-M) ・ T cell系 (CFU-T) · B cell系 (CFU-B) 幹細胞と呼び, このコロニー 形成法によつてこれらの幹細胞の同定が可能とな つている.ささらに最近では実験動物，並びにヒト の造血細胞の培養によつて，各種血球が同一コロ ニー内に混在するmixed colonyの同定が可能とな $\eta^{20) \sim 22)}$, このmixed colonyのもとになる 幹細胞 CFU-mixは，上述のCFU-Sと同じく多能性幹細胞 のレベルにあると考えられる様になつている。こ の他好塩基球のコロ ニーの形成に成功した事は上 述の通りであるが，さらに急性白血病芽球や，多 発性骨髄腫細胞など造血器腫瘍細胞からなるコ口 ニ一の形成にも成功している ${ }^{23124}$. したがつて現 在では, 組織培責法によつて殆ど全ての正常造血 幹細胞㧍よび各種造血腫瘍系幹細胞の同定が可能 になつた。孛の結果造血幹細胞自体の様々な性質， 幹細胞の分化を調節するburst promoting activity $(B P A)^{25) ~ 28)}$, erythropoietin ${ }^{29)-31)}$, granulopoietin (colony stimulating factor-CSF-) ${ }^{32)}{ }^{33)}$, thrombopoietin ${ }^{34)}$ な゙の調節因子の役割，などが次々に明 らかになつてきた。これらの問題は血球の分化の 機序を学ぶ上でまことに興味深い課題であるが， 紙数の関係もあるのでここでは主として造血幹細 胞の病態生理学的並びに臨床的意義についてのべ る。

III. 造血幹細胞の病態生理学的並ひに 臨床的 意義

ヒトの末梢血，あるいは骨髄細胞を用いて 
CFU-C，BFU-E，CFU-Eなどを同定した結果，お よびG6PDへテロ接合体の血液疾患患者を対象と して行なわれた各種血球 $G 6 \mathrm{PD}$ isoenzyme隹関す

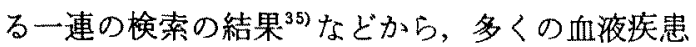
で造血幹細胞自体に異常のあることが証明されて いる．以下血液疾患を各系統の細胞別に分け，そ のおのおのについて造血幹細胞の異常とその異常 の病態生理学的, 並びに臨床的な意義について述 ベる.

\section{1. 赤血球系細胞の異常}

\section{1）再生不良性貝血}

i）再生不良性貧血に和ける幹細胞異常の病 態生理 ${ }^{36) 37}$

血液疾患の中で造血幹細胞の異常が最も早くか ら推定されていたのが再生不良性貧血である。再 生不良性貧血では周知の如く各系統の細胞の低形 成があり，その末期にはリンパ球数さ克も減少す ると報告されている。このよらな血液所見から容 易に推定されることは，本疾患に和ける多能性幹 細胞 (CFU-mix) の異常である. 又末期にはり ンパ球数も減少することは, 幹細胞の異常がより 末分化な、リンパ球も含めた全能性幹細胞(totipotential stem cell)にまで進んだためであると解 粎される。

再生不良性貧血の患者の骨㴮細胞を培着する と、その極期には赤芽球コロニー, GMコロニー共 に殆ど認められず3738),CFU-E, GM-CFUの両者, ひいてはこれらの幹細胞よりる末分化な幹細胞に 量的或いは質的な異常のある事が示唆される。 事実最近では再生不良性筫血患者では末梢血液中 のBFU-E並びにCFU-mixがともに減少すること が報告されている40141)。再生不良性貧血に対する 組織適合性の一致した骨髄の移植が有効な事は周 知であるが，この事る再生不良性貧血に和ける幹 細胞の異常の存在を示していると考えられる。

再生不良性貧血に扣けるこのような幹細胞の異 常の機序として考えられることは，放射線あるい は薬物の幹細胞に対する直接的な障害である。放 射線が幹細胞を障害することは既に数多くの動物
実験によつて明らかにされている，又数多くの抗 癌薬, あるいは抗白血病薬が幹細胞の障害を介し て骨髄の低形成をおこすことも周知である。乙か 乙臨床的に 2 次性再生不良性顀血の原因として問 題になつた，クロラムフェニュールの様な抗生物 質あるいは各種抗炎鎮痛薬の常用量が，in vivoの 条件下で造血幹細胞を直接障害するという証明は なされていない、的。

一部の再生不良性貧血の患者で，患者骨䯣中或 いは末梢血液中の単核細胞が造血幹細胞に対して 障害的に働くことが患者骨䯣細胞或いは患者木梢 血単核細胞を正常七ト骨髄細胞に加え, その添加 がGM或いは赤芽球コロニ一形成を抑制する事に よつて認められている ${ }^{43) 447}$ 。このin vitroの実験 結果は，一部の再生不良性貧血の患者の発症に免 疫学的な機序の関与することを示寸所見として注 目された。しかし再生不良性貧血の患者はしばし ば過去に輸血を受けており，輸血による感作が単 核細胞の添加による幹細胞数減少の原因であると する意見もある ${ }^{45)}$.この問題を明らかにするため に，厚生省特発性造血障害研究班では８施設36例 の再生不良性貧血患者を対象にしてその末梢血単 核細胞の造血幹細胞に対する抑制効果を険討して いる ${ }^{46)}$. その結果GMコロニーの形成に対しては 検索した29例中11例，すなわち38\%の症例でその 様なsuppressor cellの存在が 証明され，一方赤芽 球コロ =-の形成に対しては29例中 9 例 $28 \%$ ，さ らにGM-CFU並びにCFU-Eの両方に対して抑制 的に働く単核細胞は15\%に存在していた。この様 なsuppressor cellの存在が証明された症例の中には 過去に一度む輸血を受けたことのない症例が含ま れており，又検索時既に完全寛解に近い状態にあ つた症例では，いずれもこの様な単核細胞の存在 が証明されなかつた，以上の事実からsuppressor cellの存在が一部の再生不良性貧血の患者で何ら かの病熊生理学的意義を有する事が推定される. しかし反面GM-CFUK対して㧕制的であつた患 者の単核細胞がCFU-Eに 対して抑制的に働くと は限らず，GM-CFUとCFU-Eの両方に対して抑 
制的に働く単核細胞はわずか $15 \%$ の症例にしか証 明されていない点は，この様なin vitroの方法に よつて証明されたsuppressor cellに病態生理学的 な意義をもたす事にはな慎重でなければならな い事を示しているといえよう。

上述の様なsuppressor cellの本体についても不 明である。 Tリンパ球とする報告が多いが，われ われは再生不良性筫血の患者の末梢血単核細胞群 から単球を完全に取り除くとその抑制効果がなく なること，さらに再生不良性貧血患者骨髄細胞か ら食食細胞を取り除くとGM-コロニーの明らかな 增加が認められ，この現象は正常或いは他の血液 疾患ではみられないことから，再生不良性筫血に みられる幹細胞の減少に対寸る単球ーマクロファ ージの関与を強く推定している(7)48)が，同様な報 告がNissenらによつてもなされている49)。 この様 にsuppressor cellの本体打よびその病態生理学的意 義はな抢不明であるが，再生不良性貧血患者の一 部の症例で大量の副腎皮質ステロイド，免疫抑制 薬, 或いは抗りンパ球血清の投与が有効な事は数 多く報告されており ${ }^{50) ~ 531}$ ，再生不良性貧血に掠 けるsuppressor cellの存在の有無と治療の有効性 との相関を検索することは，本症の治療上重要な 意義を有しているといえよう。

再生不良性貧血でも症例によつては幹細胞の異 常ではなく，造血の微小環境に異常があるのでは ないかといら推定が以前からなされている，又最 近ではヒト骨髄細胞の培養によつて形成される主 として線維芽細胞からなるコロニーの形成が，再 生不良性貧血の患者では正常に比べて悪いことか ら，本貧血に括ける造血微小環境の異常を推定す る報告るなされている ${ }^{54)}$ ，又一卵性双生児の患者 に対する健常な兄弟の骨䯣の移植が，必ずしも常 に血液所見の軽快をむたらすとは限らないこと も，すべての再生不良性貧血で幹細胞自体だけに 異常があるのではないことを示す臨床的な事夷で あると考觉られている。

ii）再生不良性貧血に叔ける幹細胞異常の治 療的意義
表 1。再生不良性資血の病態生理
1) 造和幹細胞自体の翼常
2）造血幹細胞のまわりの異常
i）造血微小㻴境の珙常
ii）免疫学的機序による異常

以上のような所見を総合するならば，再生不良 性貧血にみられる幹細胞の異常には表 1 に示した 如く, 幹細胞自体に異常があつておこるるの以外 に, 幹細胞のまわりの造血の微小環境の異常, あ るいは上述の如き免疫学的な機序によつて 2 次的 に幹細胞が障害されるものなどがあることが推定 される，骨䯣移植は理論的には表 1 の中で，1)の 幹細胞自体に異常がある症例に対してのみ適応が あるはずであり，又免疫抑制薬や抗りンパ球血清 は，2）ii）の免疫学的機序に上る症例に対して有 効なはずである.今後各症例毎に，これらの機序 のいずれによつて幹細胞の異常がおこつたかを明 らかにすることが治療上重要になるであるら。

再生不良性貧血に対して，現在もつとる広く用 いられている薬物はフンドロゲンである。フンド ロゲンがEPO (erythropoietin)の 産生を亢進させ ることは以前からよく知られていたが，最近では アンドロゲンが造血幹細胞にも直接働き，赤血球 系幹細胞の増加をむたらすことがin vivo並びに in vitroの実験によつて証明されている ${ }^{55)}$. 再生不 良性貧血の患者に対してアンドロゲンを投与する と，数力月ののちに艺の効果があらわれることが 多い，造血幹細胞に異常がある本症では，アンド ロゲンに対する反応にも時間がかかるのではない かと推定される。造血幹細胞自体には異常がない 乳癌の患者や，腎性貧血の患者にアンドロゲンを 投与した場合にはその造血反応がより速やが打 こつてくるが，この事実も上述の推定を裏付けて いるといえるであるう。

一部の再生不良性貧血の患者は，テンドロゲン の投与によく反応して赤血球の増加を示し，アン ドロゲンの減量による貧血の増強, 增量による改 善をくり返す事がある。この様な症例をアンドロ ゲン依存性androgen-dependent $の$ 症例とよんでい 
るが ${ }^{56)}$ ，アンドロゲン依存性の症例の赤血球系幹 細胞のin vitroでのアンドロゲンに対する反応性 が他の例よりる高いかどらかは本症の治療に関連 した今後の興味ある検索の課題であるら。

重症再生不良性貧血に対寸る治療として, 最近 特に注目されているのは骨膸移植である。主とし てHLA組織適合性が 合致した兄弟の骨髄を移植 するが，最近では骨䯣移植を受けた非輸血重症再 生不良性賀血患者の生存率は $75 \%$ と対照重症例に 比べて著しく良好 ${ }^{57} て ゙ ，$ 移植成功例は殆ど治療を 要しないようになるまで回復する点が注目されて いる．わが国では兄弟数が少ないためもあつて適 当な提供者をみつけることが困難であるが，組織 適合性の合致した兄弟を有する重症再生不良性貧 血の患者に遭遇した場合には骨髄移植を行ならこ とをまず最初に考劣るべさであるう。骨髄移植が 造血幹細胞自体の移植であることはすでに広く認 められた所見であり，再生不良性貧血や急性白血 病の患者に対する骨㖪移植は, 造血幹細胞の有し ている最も大きな治療的意義の一つであるという ことができるであろう。

\section{2）赤苸球痔}

再生不良性貧血とは異なり，赤血球系細胞の 又の低形成を特徵とする赤芽球瘦pure red cell aplasia (PRCA) ではCFU-Eだけが著しく減少し， GM-CFUは通常正常範囲内にあり, 治療によつ て完全寛解に達するとCFU-Eの数も正常に復し てくることが珰められる ${ }^{54)}$.

本症ではしばしば胸腺腫が合併し，胸腺腫の摘 除によつて赤血球の産生が改善する場合のあるこ と，ステロイド薬がしばしば有効なことなどああ つて, その発症に免疫学的な機序の関与する事が 推定されていた。事実PRCAの病態に関連して, Krantzらは一部の症例で血清中に赤芽球に対して 障害的に働く免疫グロブリンの存在する事を証明 している ${ }^{58) 59}$. しかしPRCAではCFU-Eの減少が 著しい事，Krantzらの報告した血清中の阻害因子 がCFU-Eに対しても阻害的に働く可能性のある 事から考えて, 免疫学的機序による赤血球采幹細
胞の障害が本症の病態として推定される. 最近本 症の先天性型であるBlackfan-Diamond症候群の患 者の末梢血単核細胞が，CFU-Eに対して障害的に 働くことが報告されているが60)61)，この事も上述 の推定を裏付けているといえるであ万ら．PRCA に拈けるBFU-Eについての検索は未だなされて いない、しかし上述の一連の事実から考无て, 恐 らくこの疾患の患者では赤血球系の幹細胞に異常 があり，その原因として特異な免疫グロブリンの 存在，あるいは細胞性免疫の機序が関与している のであるらと考党られる。

\section{3）鉄芽球性實血}

CFU-Eの低下は再生不良性貧血, PRCAの他に 鉄芽球性貧血 (sideroblastic anemia (SA)) そ㧧い ても認められている.SAに打ける赤血球系幹細胞 の障害に関しては，Hutchesonらは5例の原発性 primary acquired SA (PASA) の患者の末梢血液 中のBFU-Eを検索し，その中の 2 例に捛いて著し いBFU-Eの低下を認めたと報告している ${ }^{62)}$. われ われは 4 例のPASA扣よびrefractory anemia with excess of myeloblast (RAEM) $)^{64)}$ ，或い怯赤白血病 に合併した 2 次性SA 3 例, 計 7 例の患者のCFUEを検索し，いずれも著しく低下していることを 証明している ${ }^{63)}$ ．興味ある事赛として原発性，2 次性を問わず，SA患者の骨髄の培養によつてわ ずかながら形成された赤芽球コロニ一の鉄染色を 行なつてみると，コロニー中の赤芽球には環状鉄 芽球が全く認められず，一方 1 数個の赤芽球の 塊恋りであるクラスタ一を形成している赤芽球に は，環状鉄芽球あるいは粗大鉄顆粒が認められた 点があげられる。なおGM-CFUはPASAでは中程 度減少から増加迄様々であつたが，RAEMや赤白 血病に伴う2 次性SAではいずれも著しく減少し ていた。

以上の事実から，SAでは原発性，2次性を問 わず正常な赤芽球になるCFU-Eと 鉄芽球になる 異常なCFU-Eの2 種類の幹細胞があり，SA患者 の骨䯣を培養すると，わずかに残存している正常 なCFU-Eからはコロニーができるが，環状鉄芽球 
を作る異常なCFU-Eはin vitroの条件下ではコロ ニーになで発育しえずクラスターに迄しかならな いのではないかと推定される。PrchalらはG6PD へテロ接合体のPASA患者を検索し，患者の末梢 血の血球は赤血球，顆粒球，血小板，リンハ球を 問わず，全て同一のG6PD isoenzymeを有してい ることから、この疾患では最も未分化な造血幹細 胞に異常があることを推定している ${ }^{64)}$. 以上の文 献的事実並びにわれわれの検索の結果を総合する ならば，原発性・2次性SAのいずれもその異常は 多能性幹細胞 (CFU-mix) のレベルで存在する が，その異常はPASAの場合にはその表現が主と して赤血球系幹細胞にあらわれるのに対して2次 性のSA，特に骨䯣の増殖性疾患儿合併したSAで は，その異常が赤血球，顆粒球の両方の系の幹細 胞にあらわれ，そのためGM-CFUの 低下や顆粒 球の異常が認められる様になるのではないかと考 えられる。

臨木的には鉄芽球性貧血では骨䯣は赤芽球過形 成を示す事が多い，したがつてこの貧血症の患者 の異常なCFU-Eは，生体内の条件では赤芽球に 迄は分化成熟し，かつ増殖しらるのであろうと考 えられる，それ以上の段階への成熟が困難な事は 本症に批る無效造血の存在からも明らかであ る.

\section{4）その他の貫血症}

CFU-Eの低下は発作性夜間血色素尿症 (paroxysmal nocturnal hemoglobinuria $(\mathrm{PNH}))$ の患者で も認められている ${ }^{37)}$. 又2次性貟血症としてしぱ しば遭遇する腎性貧血は，腎の障害によるEPO の産生低下が主要な原因であることは周知であ る. 又最近腎性貧血患者の血清中に增加している spermineがCFU-Eに対し阻害的に働らく事が証明 され ${ }^{65)}$ ，尿毒症患者にみられる赤血球産生障害の 機序の一つとして注目されている，又慢性関節り ウマチ，あるいはエリテマトーデスなどの患者に しばしば認めら机る貧血の中には，何らかの免疫 学的な機序によつて赤血球系幹細胞が障害され, その結果として赤血球産生の低下による貧血症が
颃こつてくる可能性が考壳られる．事実われわれ は，慢性関節リウマチの患者のリンパ球が赤血球 系幹細胞を障害することを示咬する結果を得てい $る^{66)}$.

\section{5）真性多血症}

真性多血症患者の骨髄細胞を培着すると，一般 飞赤芽球コロ二一が増加し，又顆粒球数の多い症 例ではGMコロニーも増加している事が認められ

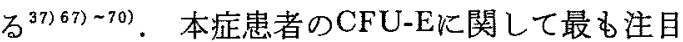
される事は，正常骨髄細胞ではEPOの存在なしに は赤芽球コロニーの形成が認められないのに反し て，真性多血症の患者ではEPOの存在なしに赤 芽球コロニ一の形成が認められる点である ${ }^{71)}$. ᄂ かし真性多血症患者の骨髄細胞でるその培地内に EPOを添加すると，添加量の堌加に平行して赤芽 球コロニーの数がさらに增加することが㒛められ る.この事から，この疾患ではEPO依存性の有無 によつてわけられる 2 種類の赤血球系幹細胞の存 在する事が推定された。しかし培地内に抗EPO 抗体を添加すると赤芽球コロニーが全く出来なく なる ${ }^{71}$ 事から，最近では真性多血症患者のCFU-E はEPOに対する感受性が異常に高く，そのため 培地内に血清などの形で混入した微量のEPOK 反応して，外からのEPO添加がなくても赤芽球 コロニーをつくりらるのではないかと考觉られる 様になつている。

G6PDへテロ接合体の真性多血症患者の末梢血 を調べてみると，赤血球，顆粒球，血小板はいず れも同一のG6PD isoenymeを有していると報告さ れている ${ }^{72)}$ 。この事実から，真性多血症は 1 個の 多能性造血幹細胞の異常から始まり，臨床的にそ の存在が発見された時には異常な幹細咆のクロー ンから由来した血球が末梢血液中で大勢を占める 様になつていたと考えられる。さらにG6PDへデ 接合体患者の骨䯣細胞を培養し，各赤血球コ口ニ 一のG6PD isoenzymeを調べたPrchalらの検索の 結果では, 各コロニーを形成する赤芽球は一種類 のisoenzymeを有して㧍り，培地内のEPOの濃度 が低い時には全てのコロニーが末梢血の血球と 
同じG6PD isoenzymeを有しているが，添加する EPOの濃度をさらに增加させると，異なつた G6PDisoenzymeを有する正常CFU-E由来亡考え られる赤芽球コロニーが，少数ながら出現するこ とが認められている ${ }^{73)}$.

真性多血症は後天性疾患であり，当然正常な赤 血球系幹細胞のクローンが残存しているはずであ る、々の事が高濃度のEPO下で，わずが認め られた他のコロニーとは異なつたisoenzymeを有 する赤芽球コロ=ーの出現として示されたのであ ろう．この正常CFU-E由来と考方和る赤芽球 $=\square=-s^{\prime}$, 同一症例で病気の進行に伴つて次第 に減少していく事が報告されて扣り興昧深い、年). 真性多血症患者の生体内には，EPOに対する反応 性が異なる 2 種類のCFU-Eがあり，真性多血症患 者の様に血清EPOが低い状態の時には，EPOに 対する感受性が高い異常なクローンのCFU-Eか らの赤血球系細胞の分化が行なわれているのであ 万弓。な批2 次性多血症は，EPO産生腫瘍に上 ると考光られる症例を含めて，その殆どすべてが 血清EPO值の異常な高值によつておこつてきた わのである ${ }^{75)}$.

\section{2. 顆粒球系細胞の異常}

1) 急性白血球

i）急性白血病に批汁幹細胞異常の病態生 理

顆粒球系細胞の異常の中で, 造血幹細胞との関 連でその病態生理が最も注目されているのは白血 病で方る，急性骨䯣性白血病 (acute myelogenous leukemia (AML))患者の骨髄細胞を培養し, GMCFUあるいはCFU-Eの変化をみてみると，白血 病芽球が堌加する増悪期には全ての症例でいずれ も著しく減少している事が認められる ${ }^{76) \sim 80)}$. 急 性白血病患者の骨髄細胞を培養すると，少数の細 胞からなるクラスターの出現を認めることがあ り，症例によつてはその数の著しい場合がある が，その多くは白血病芽球が集合或いは㦈殖して 出来たものと推定される。

急性白血病の患者が通常の治療によつて完全寛
解に到達すると，GM-CFUあるいはCFU-Eが共 に正常值に復し，先の後白血病に対する地固め， 強化療法を行ならと，その度毎にこれらの幹細胞 の数が減少し，再び自然にもとの值に迄回復する 事がくり返し認められる ${ }^{811}$. 経過の観察中白血病 が増悪するとGM-CFUの数が再び減少するが, その祭末梢血の变化に先立つてコロニ一数が隇少 する場合があるため，GMュロニ一数の算定は， もしも簡便に行なわれる様になれば白血病の悪化 を事前に知る臨床的な方法となる可能性が考えら れる。

急性白血病では，末梢血で白血病芽球と成熟顆 粒球のみが混在する白血病裂孔（hiatus leucemicus）が認めら机る事，又強力な化学潦法によつ て患者が完全寬解に達すると，正常と殆ど区別の つかない血液像を呈し，極期にみられた染色体の 異常もしばしば消失することなどから，急性白血 病は多能性幹細胞のレベルでおこつており，患者 の骨髄中には白血病化した幹細胞と正常な幹細胞 の両者が共存していることが考えられる．恐らく 増悪期には白血病性幹細胞のプールが増大し，そ れに伴って正常幹細胞のプールが減少するのであ ろ5. 白血病の増悪汇伴ら正常幹細胞プールの減 少の機序の一つとして，白血病性細胞怔正常な幹 細胞の分化・成熟を直接阻害することをわれわれ

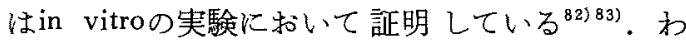
れわれは又骨䯣中の芽球の\%が $40 \%$ 以上の患者で はGMュロニーの形成が殆ど認められなくなる事 をみているが，このことから，白血病芽球による 正常幹細胞の障害が生体内以括いても何らかの病。 態生理学的意義を有しているのではないかと考え られる。

ii）白血病に打讨る造血幹細胞異常の治療的意 義

急性白血病患者の末梢血或いは骨䯣の細胞を PHA刺激ヒトリンパ球培盖上清と共に培養する 事によつて, 白血病芽球からなるコロニ一の出来 ることが著者らの所を含めたいくつかの研究グ ループから報告されている防35)84) -86)。通常白血 
病芽球の比率の高い末梢血, 骨䯣細胞を血浆塊中 で，上記PHA刺激末梢血培責上清と共に培養す ると，培地中に入れた白血病細胞の数と形成され る白血病性コロニーの数との間比原点を通る直線 関係が認められ，このことから1個の白血病芽球 コロニーが 1 個の白血病性幹細胞から由来すると 考えられる。

白血病性幹細胞の同定は白血病の病態の解明ば かりでなく，治療の上からむ極めて重要な意義を 有している，例えば患者の抗白血病薬に対する臨 床的効果を決定するのは，正常幹細胞と白血病性 幹細胞の両者の間の薬物感受性に対する相違であ る.したがつて正常の幹細胞よりも白血病性幹細 胞をより強く障害する薬物を，個々の白血病症例 に括いて同定する事がもつとる望ましいと考兄 られる。事実Buick ${ }^{87}$ らは白血病性幹細胞のadriamycin，或いはdaunomycinなどの抗白血病薬に対 する感受性が正常の幹細胞と異なることを譛めて いるが，われわれる上記薬物の他cytosine arabinoside, vincristine, methotrexateでも同椂な現象 のみられる事を確認している。これらの薬物に対 する感受性は，個々の症例の白血病性幹細胞によ つて異なつていると推測される。将来白血病性幹 細胞の薬物に対する感受性を，簡単かつ迅速に測 定する事が出来るようになつたならば，個々の白 血病患者に遭遇した場合，症例毎により特異性の 高い治療を行ならことができるようになるである 5 .

急性白血病の幹細胞が条件によつて成熟顆粒 球に迄分化しうるかどうかは，白血病の治療に 関連した重要な問題である。ママウス白血病のM 細胞や上卜白血病細胞由来のHL 60 や5 $562 か ゙ ，$ in vitroの条件下で分化しらる事が報告されてい $る^{88) \sim 92)}$. 又小動物の腹腔内のdiffusion chamber の中という条件下で，白血病細胞が成熟したとい ら報告むなされている。臨枺的にも白血病性細胞 からの由来を思わせる様な，異常な形態を示す成 熟顆粒球が出現する様な希な症例に遭遇する場合 がある。しかしin vitroやin vivoの条件下で一見
分化した様にみえても，その細胞が白血病性幹細 胞由来であるかぎり，その腫瘍としての性質は潜 在的な形ででもらけつがれており，条件次第では 再び明らかな芽球化を示してくると考えられる。

したがつてCSFなどによつて白血病性幹細胞に正 常の分化を打こさせる様な治療法は現段階では考 えられず，以下述べる骨髄の移植がより現実的な 治療法であるといえよ5。

急性白血病に和ける造血幹細胞異常の治療的意 義として特に注目されるのは骨髄移植で，この治 療法が積極的に行なわれる様になつてきている事 は周知である，特に良好な成績をあげているのは シアトルのED Thomasらのグループで，彼らは 従来の如く再発をくり返した白血病症例に対して ではなくて，急性骨髄性白血病の場合には第 1 回 目，急性リンパ性白血病の場合には第 2 回目以後 の完全寛解期に同胞の骨䯣細胞を移植し，極めて 良好な結果が得られたと報告している ${ }^{93)}$. 特に骨 檤性白血病の場合には48例中の 31 例 $(65 \%)$ が 2 $\sim 4$ 年生存し, さらに被移植患者の年令が30才以 下で，完全寛解期に骨髄移植を受けた急性骨䯣性 白血病患者の $75 \%$ が 2 年以上生存していると報告 しているが94), この值は従来の化学療法に比べて はるかに良い值である、したがつてHLA組織適 合性が合致した兄弟がいる急性白血病の患者に詨 しては，骨髄移植を積極的に考えるべきであるう。

適当な骨髄提供者のいない患者の場合でも骨髄 移植の適心が全くないとはいえない。なぜならば 完全寬解期に入つた患者の骨髄細胞を凍結保存 し, 増悪期治力な化学療法のあとに凍結保存し た自己の骨髄を移入することが試みられているか らである．正常な幹細胞が長期の凍結保存に耐兄 らることは，既に証明されている汭96)。この際完 全寛解期に打いても，な就存している白血病幹 細胞を何らかの方法で分離, 或いは死隇させるこ とが行なわれるよらになつたならば，骨髄の瑓結 保存はより大きな臨床的意義を有するようになる であろ5，又同時飞白血病性幹細胞が特定の凍結 保存に対してどの様な感受性を有しているかを検 
索することは，極めて重要なかつ興味ある研究で あろら。

\section{2）慢性骨鲔性白血症}

i）慢性骨䯣性白血病に括沙る幹細胞の変動 慢性骨髄性白血病 (chronic myelogenous leukemia (CML)) は染色体マーカーである $\mathrm{Ph}^{1}$ を有 しており，このマーカーが白血球系細胞ばかりで なく赤血球並びに血小板系の幼若細胞，さらにマ クロファージにも認められる ${ }^{97798} こ と か ら$, 本症 では造血幹紐胞に異常のあることが以前から考え られていた．最近のFialkowらによるG6PDへテロ 接合体の患者の検索では，赤血球・顆粒球・血小 板並びにB cellが同一のisoenzymeを有する買常な クローンから由来することが証明されており影， 恐らく慢性骨髄性白血病ではリンパ球を含めた全 能性幹細胞のレベルで白血病化が和こつていると 考えられる。

上述の様な考皃を支持するもら一つの根拠とし て，CMLが急性転化を抗こした場合にリンパ球 の性質を多く有する芽球が 出現してくる事実が あげられる ${ }^{1002 \sim 103)}$ ，特に最近急性転化例の 約 $1 / 3$ の症例で芽球中に高いterminal deoxynucleotidyl transferase (TdT) 活性が証明されることが注目

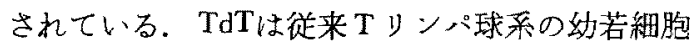

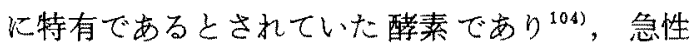
転化時にこの酵素の活性が証明されるようになつ たのは, 白血病化に伴つてより未分化な造血幹細 胞の性質の一部が表現される様になつたためでは ないかと考えられる。

CMLに打哄常な幹細胞は急性白血病の場 合と異なり，in vivo並びにin vitroの状態でいず れる分化成熟する事が可能である ${ }^{80)}$ ，又CMLで はGM-CFUが骨髄で正常の10倍，末梢血では2000 倍にも増加している事が報告されているが，われ われはCFU-E。同時に正常より増加している事

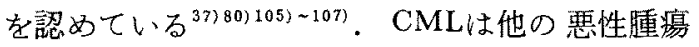
と同様に後天的におこつてくる疾患であり，当然 急性白血病の場合と同じょうに正常幹細胞のクロ ーンと白血病化した幹細胞のクローンの両方が存
在するはずである，しかしCMLでは抗白血病薬 による治療によつて白血球数が正常化し，貧血が 改善して子通常 $\mathrm{Ph}^{1}$ 染色体が陽性で，好中球アル カリフォスファターゼの值も低いままである, 又 上述のG6PDへテロ接合体の患者の末梢血球G6PD isoenzymeの検索の 結果から考之て，病期の如何 に拘わらず末梢血液中に存在する血液細胞は殆ど 全て異常な幹細胞のクローンから由来していると 考点られる。CMLに和ける残存正常幹細胞の割 合に関して，Fialkowらは5例のG6PDへテロ接合 体CML患者の骨髄細胞からGMコロニーをつく り, 各コロ =ーのG6PD isoenzymeを検索した結 果, 1306個の 1 種類のG6PD isoenzymeのコロ二 一と 2 個の他種類のisoenzymeのコロニーを認め たと報告している ${ }^{108)}$ ，従つてCMLの場合には急 性白血病に比べて異常な幹細胞のプールが非常に 大きく正常のプールは極めてわずかであり，それ だけ治療が困難である，又真性多血症の場合と同 じ様に経過が長びくにつれて，正常の幹細胞のプ ールが次第に減少する事が推定される。

ii）幹細胞からみ大慢性骨䯣性白血病の治療 CMLの患者で一時的にせよ $\mathrm{Ph}^{1}$ 染色体が消失 し, 又アルカリフォスファターゼが正常化する様 な完全寛解に 到達する症例は極めてわずかであ り，通常強力な治療を受けた患者にだけみられ る事が報告されている109)-111)，通常われわれは CMLの患者に対してはアルキル化薬の少量投与 を行ない，やがて患者が急性転化をおこして死亡 するのを座視している様な状態であるが，上述の 如く,CMLでは正常な造血幹細胞に比べて白血病 性幹細胞のプールが著しく大きいので，CMLの 患者で急性白血病にみる様な完全寛解を得るため には急性白血病よりる，上り強力な治療をする必 要があるのてはないかと考亲られる，又CMLの 患者に対する骨髄移植も十分に考虑すべきである 5.上述の如く，CMLでは異常な幹細胞から由 来したGM-CFUとCFU-Eが共に正常よりる增加 している.脾缄も血球の産生に参加しているし， 末梢血液中に多数のGM-CFUが存在している. 
したがつてこの疾患では異常な造血幹細胞の数が 全身的に著しく増大していると考充られ，その体 内からの除去は極めて強力な化学療法と骨髄移植 の組合わせ以外の方法では非常に困難であろう。

自己骨䯣の移植の臨床的応用に関してはCML は極めて有望である.CML患者の末梢血中に多数 のGM-CFUの存在することが証明されているの で,慢性期の末梢血白血球を保存し，患者が急性転 化をおこした時に強力な化学療法のあとに保存し た慢性期の白血球を輸血し，造血能の回復をはか ることが可能である。しかしその場合には本来の 同種骨髄移植の場合と異なり，完全な寛解は望め えず，ただ急性転化時の患者の状態を元の慢性期 の状態にもどすだけの意味しかないであるう。

\section{3. その他の顆粒球系疾患}

i) 骨䯣線維症

造血幹細胞の病態生理に関連して興味あるもの の一つに骨髄線維症がある。骨髄線維症は以前か ら骨髄中に怙ける線維芽細胞の異常かつ自律性 の増殖によつておこつてくると考光られていた。

しかLG6PDへテロ接合体の骨䯣線維症患者を使 つた検索の結果，本症の患者でも赤血球，白血 球，血小板がいずれも異常なクローンから由来す る同一のisoenzymeを有することが証明されてい $る^{112)}$. 逆に患者骨髄から培亘した線維芽細胞は 2 種類のG6PD isoenzymeを有することから，骨䯣線 維症は白血病の場合と同じょうに，その異常が多 能性造血幹細胞のレベルで执こつていると考元ら れる，骨剈道線維症の患者ではしぱしば末梢血液中 にGM-CFUが增加しているが氵1132，末梢血液中に 打ける幹細胞の增加が，本症患者にみられる䯣外 造血の主要な原因であ万弓，本症において何故骨 䯣の線維化が扣こるかその機序は不明であるが， 近年血小板系細胞中の線維細胞を増殖させる因子 すなわちfibroblast growth factor (FGF) 飞類似し た性質をるつ増殖促進因子，すなわち血小板由来 成長因子 (PDGF) ${ }^{114}$ の存在が 血小板と動脈硬化 の進展とに関連して注目されている ${ }^{115)}$ ，骨剈道線 維症にみられる骨䯣の線維化の機序として，この
FGFの骨䯣線維芽細胞に対する作用が推定されて いる ${ }^{116\rangle}$ 事は與味樑い。

ii）前白血病状態

いわゆる前白血病状態として再生不良性貧血, 鉄芽球性貧血，発作性夜間血色素尿症などがあげ られているが，これらの疾患ではいずれす造血幹 細胞に異常がみとめられることは上述の幹細胞の 白血病化を示唆する所見として極めて興味深い。

これらの疾患よりも，ょり白血病に近いと考え られるmyelodysplasia特にrefractory anemia with excess of myeloblast (RAEM) に执ける幹細胞の 異常の検索については前述の通りであるが，前 白血病状態として知られているRAEMでCFU-E, GM-CFUが共に著しく減少している事は病態生 理学的にも又診断的にも重要な意義を有している と考えられる.

RAEM 類似した血液像を呈する疾患に， 慢性骨髄単球性白血病 (chronic myelomonocytic leukemia (CMMoL)) がある。CMMoLは末梢 血夜中で単球が，又骨髄中では芽球の\%が高く， から慢性に 経過する疾患であるが，われわれは CMMoLの患者骨髄細胞の培養ではGM-コロニ 一が正常の場合よりも扰くれて出現することを認 めている ${ }^{117)}$. CMMoLでも他の白血病の場合と 同じ様に幹細胞に異常があり，その表現形として このようなコロニー形成の異常ハターンを示して くるのであるら.

以上の様な事実からGM-CFUに明らかな量的 或いは質的な異常を認める患者に遭遇した場合に は，その血液像の如何を問わず前白血病状態であ る可能性を考兄, 患者の経過を注意深く追う必要 があるである5。上述の如く，同じ様に鉄芽球性 貧血の血液像を呈しながらPASAの場合にはGMCFUの減少が明らかでないのに対し，前白血病 状態と考兄られるRAEMではGM-CFUの減少が 著しく，しかも白血病になる頻度はRAEMの方が PASAに比べて著しく高い。このこともGM-CFU の減少之前白血病状態とを関連づする考支を支持 する所見であるといえよう。 
iii）好中球減少症扩よび増加症

ヒトおよびgray collie犬にみられる周期性好中 球減少症 (cyclic neutropenia) 方，生体内に和け る顆粒球産生の調節機構を研究するための疾患と して注目されている ${ }^{118) 119)}$ イイ邓のcyclic neutropeniaでは顆粒球だけでなく，他の血球の産生も周 期的に变化し，骨䯣移植に上つて好中球減少症の

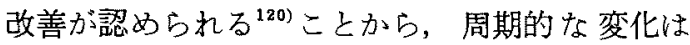
造血幹細胞の異常によつておこつたものであると 考光られている。 ヒトのcyclic neutropeniaに関し ては血中拈よび尿中のCSFのレベルが末梢血液中 の単球の数の変動とほほ平行して，周期的に変動 することが報告されている゙21). 又 peniaの患者では，骨骵中のGM-CFUの数やDNA 合成能が好中球の変動に逆比例して変化すること も報告されている 験した症例の観察では，好中球のサイクルル伴ら GM-CFUの変動はわずかで，GM-CFUュロニー の形成に 対する阻害因子が周期的に変動してい $\star^{123)} こ と か ら$, cyclic neutropenia の病態の多様 性が推定される。

先天性好中球減少症に打流顆粒球生成の状態 についての検索の結果は様々で，たと壳ばYamenite Jewの先天性好中球減少症ではGM-CFUは増

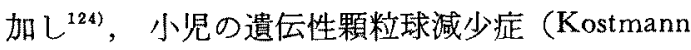
syndrome）ではGM-CFUが正常であつたと報告さ れている ${ }^{125)}$. 好中球減少の機序としてはCSF座 生の欠如，幹細胞自体の異常，無効顆粒球産生の 様な顆粒球成熟の異常，顆粒球破塄の九進，顆粒 球分布の異常，これらの組合せなどが考方られて おり，又in vivoでの顆粒球の産生とin vitroの培 盖条件下でのGMュロニーの形成とが異なつた態 度をとる事す示されている。この様に各種好中球 の減少の機序については不明な点が少なくない が，今娞幹細胞とCSFの両者を検索する事によつ てその病態がより明らかになつてくるであらら。

好中球増加症の中では肺癌その他の悪性腫瘦に 伴う好中球増加症が問題になつている この場合成熟好中球の異常増加が特改的で，腫癔
組織からCSF活性が証明される事が多く, 又ヌ一 ドマウスに䔟植するとそのマウスに好中球増加の 揖こる事から，CSF座生腫瘍ではないかと考えら れている.

\section{4.その他の血球系の異常}

血小板血症は血小板の簧常増殖と増殖した血小 板の機能異常による出血傾向を主な病態とする疾 患であるが，この疾患の場合にも恐らく他の系統 の血球の異常増殖の場合と同じょ5に多能性造血 幹細胞に異常があり，その表現形として血小板の 異常な産生が物こつてくるのであるらと推定され る。しかし未たヒヒトの核球系幹細胞の同定は極

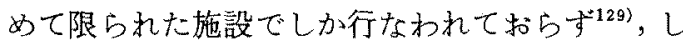
たがつて血小板血症に挌いて㙕加している血小板 が正常なクローンから由来する血小板の異常な増 加であるのか，あるいは異常な血小板系翰細胞か ら由来したものであるのかその本態はな和不明て ある。

この他最近ではT，Bリンパ球系コロニーの形 成名行なわれるよらになつており，兔疫不全状態 に嗍けるこれらのコロニーの動態が問題になつて いるが紙数の関係上省略したい．

\section{IV. 終わりに}

以上造血幹細胞に関する現在までの知見の概要 を述ベると共に造血幹細胞の異常の病態生理学 的，あるいは治療的な意義につき各系統の血球毎 にその概略を述べた。造血幹細胞の臨床的な意義 については現在でも，な招多くの新しい事が見出 されている。紙数の関係もあり，十分に述べるこ とができなかつたが，造血幹細胞についてはすで に数多くの本, reviewむあるので興味のある方は 文献闀に紹介した論文を参照されたい、な就本維 説では従来の様に自分達の仕事を紹介するといら よりを,この問題についてのレビューを行ない, 私共の仕事は文献引用のかたちで随時紹介した。

\section{文献}

1) Metcalf D: Hemopoietic Colonies. SpringerVerlag, Berlin, Heidelberg, New York, 1977.

2) Golde DW, et al: Hematopoietic Cell Differ- 
entiation. Academic Press, New York, 1978.

3) Nowell PC, et al: Evidence for the existence of multipotential lymphohemopoietic stem cells in adult rat. J Cell Physiol 75: 151, 1970.

4) Abramson J, et al: The identification in adult bone marrow of pluripotent and restricted stem cells of myeloid and lymphoid systems. J Exp Med 145: 1567, 1977.

5)高久史鹰：血球生成の調節とその異常, 血液の 病態生化学。高久史厤，承上茂樹編，朝會畫 店, 東京, $1979, \mathrm{p} 1$.

6) Murphy MJ Jr, Ed: In Vitro Aspects of Erythropoiesis. Springer-Verlag, New York, 1978.

7) Axelrad AA, et al: Properties of cells that produce erythrocytic colonies in vitro. In RobinsonWA: Hemopoiesis in Culture. Washington, DC, US Government Printing Office, 1974.

8) Iscove NN and Sieber F: Erythroid progenitors in mouse bone marrow detected by macroscopic colony formation in culture. Exp Heat 3: 23, 1975.

9) Heath DS, et al: Separation of the erythropoietin-responsive progenitors BFU-E and CFU-E in mouse bone marrow by unit gravity sedimentation. Blood 47: 777, 1976.

10) Kitamura $Y$, et al: Local control of mast cell differentiation in mice. Exp Hemat Today, 1979. Springer-Verlag, New York, 1979, p 45.

11）*溝口秀昭，他：七下好塩基球産生に関与る研究 （1）好塩基球 $ロ=-$ 形成細胞について，日血 会誌, $43: 158,1980$.

12) Till JE and McCulloch EA: A direct measurement of the radiation sensitivity of normal mouse bone marrow cells. Rad Res 12: 213, 1961.

13) Iscove $\mathrm{NN}$, et al: Colony formation by normal and leukemic human marrow cells in culture: Effect of conditioned medium from human leukocytes. Blood 37: 1, 1971.

14) Metcalf D, et al: Formation of eosinophiliclike granulocytic colonies by mouse bone marrow cells in vitro. J Cell Physiol 84: 275, 1974.

15) Nakeff A, et al: Megakaryocytes in agar cultures of mouse bone marrow. Ser Haemat 8: 4,1975 .

16)* Mizoguchi $\mathrm{H}$, et al: An improved plasma culture system for the production of megakaryocyte colonies in vitro. Exp Hemat 7 : 345,1979
17) Srendi B, et al: Development of colonies in vitro of mitogen-stimulated mouse T-lymphocytes. Nature 259: 130, 1976

18) Rozenszajn LA, et al: Clonal proliferation of PHA-stimulated human lymphocytes in soft agar culture. Immunology 29: 1041, 1975.

19) Metcalf D, et al: Growth of B-lymphocyte colonies in vitro from mouse lymphoid organs. Nature 255: 630, 1975.

20) Johnson GR and Metcalf D: Pure and mixed erythroid colony formation in vitro stimulated by spleen conditioned medium with no detectable erythropoietin. Proc Natl Acad Sci 74: 3879, 1977.

21) Hara J and Ogawa M: Murine hemopoietic colonies in culture containing normoblasts, macrophages, and megakaryocytes. Amer J Haematol 4: 23, 1978.

22) Fauser AA and Messner HA: Identification of megakaryocytes, macrophages and eosinophils in colonies of human bone marrow containing neutrophilic granulocytes and erythroblasts. Blood 53: 1023, 1979.

23) Minden MD, et al: Separation of blast cell and T-lymphocyte progenitors in the blood of patients with acute myeloblastic leukemia. Blood 54: 186, 1979.

24) Park $\mathrm{CH}$, et al: Mouse myeloma tumor stem cells: A primary culture assay. J Natl Cancer Inst $46: 411,1971$.

25) Iscove NN: Erythropoietin-independent stimulation of early erythropoiesis in adult marrow cultures by conditioned media from lectinstimulated mouse spleen cells. Ref 2) p 37, 1978.

26) Iscove NN and Guilbert LJ: Erythropoietin independence of early erythropoiesis and a tworegulator model of proliferative control in the hemopoietic system. Ref 5) p 3, 1978.

27) Wagemaker G: Cellular and soluble factors influencing the differentiation of primitive erythroid progenitor cells (BFU-E) in vitro. Ref 5) p 44, 1978.

28) Cline MJ and Golde DW: Cellular interections in hematopoiesis. Nature 277: 177, 1979.

29) Krantz SB and Jacobson LO: Erythropoietin and Regulation of Erythropoiesis. Univ Chicago Press, 1970.

30) Gordon AS: Erythropoietin. Vit Horm 31: 105, 1973.

31)* Nakao K, et al Eds: Erythropoiesis. Univ of Tokyo Press, 東京, 1975. 
32) 高久史椟：顆粒球産生の調節：特K=ロ=座生刺㦸因子 (CSF) の病態生理学的意義. 医 学のあゆ友 95:41，1975.

33) Brennan JK, et al: Chemical mediators of granulopoiesis: A review. Exp Hemat 8: 441, 1980.

34)*满口秀昭：トロンボポエチン。医学のあゆみ $114: 517,1980$.

35) Fialkow PJ: Clonal and stem cell origin of blood cell neoplasmas. In Contemporary Hematology/Oncology. Vol 1: 1, LoBue J, et al Eds. Plenum, New York, 1980.

36) 高久史榣：造血幹細胞口変動：再生不良性缶 血, 日比野進, 高久史噟編, 医学書院, 東京, 1979 , p 41 .

37) 高久実磨：造血幹細胞の臨床。臨床血液 21 : 125, 1980

38) Kurnick JE, et al: In vitro granulocytic colony-forming potential of bone marrow from patients with granulocytopenia and aplastic anemia. Proc Soc Exp Biol Med 137: 917, 1971.

39)* Mizoguchi $\mathrm{H}$, et al: CFU-E and CFU-C in various hematological disorders. Hematologica $63: 444,1976$.

40) Hansi W, et al: Erythroid colony forming cells in aplastic anemia. Brit J Haemat 37: 483, 1977.

41) Hara H, et al: Pluripotent hemopoietic precursors in vitro (CFU mix) in aplastic anemia. Exp Hemat 8: 1165, 1980.

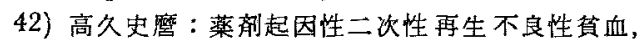
再生不良性贫血，日比野進，高久史鹰編，医 学書院, 東京, 1979, p 99.

43) Ascensāo J, et al: Aplastic anemia: Evidence for an immunological mechanism. Lancet 1: $669,1976$.

44) Hoffman R, et al: Suppression of erythroidcolony formation by lymphocytes from patients with aplastic anemia. New Eng J Med 296: 10, 1977.

45) Singer JW, et al: Effect of peripheral blood lymphocytes from patients with aplastic anemia on granulocytic colony growth from HLA-matched and -mismatched marrow: Effect of transfusion sensitization. Blood 52: $37,1978$.

46) Takaku F, et al: Effect of peripheral blood mononuclear cells from aplastic anemia patients on the granulocyte-macrophage and erythroid colony formation from normal human bone marrow in vitro-A cooperative work. Blood 55: 937, 1980.

47)* Suda T, et al: Enhancement of granulocytic colony formation by deletion of phagocytic cells in the bone marrow of patients with aplastic anemia. Exp Haemat 8: 659, 1980.

48) Takaku F, et al: Suppressive effect of the phagocytic cells in the peripheral blood and the bone marrow of the patients with aplastic anemia on in vitro colony formation. Exp Hemat 8 (Suppl 7): 88, 1980.

49) Nissen C, et al: Peripheral blood cells from patients with aplastic anemia in partial remission suppress growth of their own bone marrow precursors in culture. Brit J Haemat 45:233, 1980.

50) Speck B, et al: Treatment of aplastic anemia by antilymphocyte globulin with or without allogenic bone marrow infusion. Lancet 2: $1145,1977$.

51) Amare $M$, et al: Aplastic anemia associated with bone amrrow suppressor $T$ cell hyperactivity. Successful treatment with antithymocyte globulin. Clin Res 25: 333A, 1977.

52) Bacigalupo A, et al: Bolus methylprednisolone in severe aplastic anemia. New Eng J Med 300: 501, 1979.

53) Baran DT, et al: Recovery from aplastic anemia after treatment with cyclophosphamide. New Eng J Med 295: 1522, 1976.

54) Wiktor-Jedrzejczak W, et al: Aplastic anemia with marrow defective in formation of fibroblastoid colonies. Exp Hemat 8 (Suppl 7): $89,1980$.

55) Shahidi NT: Androgens and erythropoiesis. New Eng J Med 289: 72, 1973.

56) Azen EA and Shahidi NT: Androgen dependency in acquired aplastic anemia. Amer J Med 63: 320, 1977.

57) Storb $R$, et al: Marrow transplantation in thirty "untransfused" patients with severe aplastic anemia. Ann Int Med 92: 30, 1980.

58) Krantz SB and Kao V: Studies on red cell aplasia I. Demonstration of a plasma inhibitor to heme synthesis and an antibody to erythroblastic nuclei. Proc Natl Acad Sci 58: $493,1967$.

59) Krantz SB, et al: Studies on pure red cell aplasia. V. Presence of erythroblast cytotoxicity in globulin fraction of plasma. J Clin Invest 53: 324, 1973.

60) Hoffman R, et al: Diamond-Blackfan syn- 
drome: Lymphocyte-mediated suppression of erythropoiesis. Science 193: 899, 1976.

61) Nathan DG, et al: Erythroid precursors in congenital hypoplastic (Diamond-Blackfan) anemia. J Clin Invest 61: 489, 1978.

62) Hutcheson JR, et al: Idopathic sideroblastic anemia: Presence of sideroblastic changes in the erythropoietic precursors cultured from peripheral blood. Exp Hemat 7: 328, 1979.

63) Takaku F, et al: Erythroid precursor cells in primary acquired and secondary sideroblastic anemia. Exp Hemat 8(Suppl 8) : 225, 1980.

64) Prchal JT, et al: A common progenitor for human myeloid and lymphoid cells. Nature 274: 590, 1978.

65) Radtke HW: Characterization of an inhibitor of erythropoiesis in chronic renal failure: In vitro studies in fetal mouse liver cell culture. Exp Hemat 8(Suppl 8): 298, 1980.

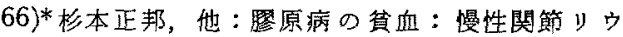
マチ患者骨䯣赤芽球の一么合成々それに执上ぼ す antithymocyte globulin の影锌。第8回日本 臨床免疫学会䍃会, 1980, 東京。

67) 满口秀昭, 高久史黁 : 赤血球增多症 : 真性赤血 球增多症の病態生理，特心血液幹絊胞の動態。 臨床血液 $15: 237,1974$

68) Kimura $\mathrm{H}$, et al: Erythroid colony formation in vitro in bone marrow cells of polycythemia vera. Acta Hemat Jap 41: 679, 1978.

69) Moore MAS: In vitro studies in the myeloid leukemia. In Advances in Acute Leukemia. Cleton FJ, et al Eds. North Folland, Amsterdam, 1975, p 161.

70) Zanjani ED, et al: Erythroid colony formation by polycythemia vera bone marrow. In vitro dependence on erythropoietin. J Clin Invest 59: 841, 1977.

71) Prchal JD and Axelrad AA: Bone marrow responses in polycythemia vera. New Eng J Med 290: 1382, 1974.

72) Adamson JW, et al: Polycythemia vara: Stem cell and probable clonal origin of the disease. New Engl J Med 295: 913, 1976.

73) Prchal JF and Adamson JW: Polycythemia vera: The in vitro response of normal and abnormal stem cell lines to erythropoietin. J Clin Invest 61: 1044, 1978.

74) Adamson JW: Polycythemia vera. The use of cell markers in studies of hematopoietic regulation. 18th Cong Int Society Hematology,
Montreal, 1980.

75) Balcerzak SP and Bromberg PA: Secondary polycythemia. In Polycythemia: Berlin NI, et al Eds, Grune \& Stratton, New York, 1976, p 19.

76) Senn JS, et al: Comparison of colony-forming ability of normal and leukemic human marrow in cell culture. Lancet 2: 597, 1967.

77) Iscove NN, et al: Colony formation by normal and leukemic human marrow cells in culture. Blood 37: 1, 1971.

78) Robinson WA and Pike BL: Colony growth of human bone marrow cells in vitro. In Hematopoietic Cellular Proliferation. Stohlman F Jr, Ed, Grune \& Stratton, New York, 1970, p 249.

79) Brown $\mathrm{CH}$ and Carbone PP: In vitre growth of normal and leukemic human bone marrow. I Natl Cancer Inst 46: 989, 1971.

80) Moore MAS, et al: In vitro colony formation by normal and leukemic human hematopoietic cells: Characterization of colony-forming cells. J Natl Cancer Inst 50: 603, 1973.

81)* Kubota $\mathrm{K}$, et al: Serial studies on in vitro colony formation in patients with acute leuke$\mathrm{mia}$ in relation to the maintenance of remission. Amer J Haemat 5: 285, 1978.

82)* Chiyoda $\mathrm{S}$, et al: Influence of leukaemic cells on the colony formation of human bone marrow cells in vitro. Brit J Cancer $31: 355$, 1975.

83)* Chiyoda S, et al: Influence of leukemic cells on the colony formation of human bone marrow cells in vitro. II. Suppressive effects of leukemic cell extracts. Brit $\mathrm{J}$ Cancer 33: 379, 1976.

84) Minden $\mathrm{MD}$, et al: Proliferative state of blast cell progenitors in acute myeloblastic leukemia. Blood 52: 592, 1978.

85) Park $\mathrm{CH}$, et al: Prediction of chemotherapy response in human leukemia using an in vitro chemotherapy sensitivity test on leukemic colony-forming cells. Blood 55: 595, 1980.

86) Park $\mathrm{CH}$, et al: Improved growth of in vitro colonies in human acute leukemia with feeding culture method. Cancer Res 37: 4595, 1977.

87) Buick RN, et al: Cytotoxicity of adriamycin and daunorubicin for normal and leukemia progenitor cells of man. J Natl Cancer Inst $62: 349,1979$.

88) Ichikawa Y: Differentiation of a cell line of myeloid leukemia. J Cell Physiol 74: 223, 
1969.

89) Gallagher R, et al: Characterization of the continuous differentiating myeloid cell line (HL-60) from a patient with acute promyelocytic leukemia. Blood 54: 713, 1979.

90) Koeffer HP and Golde D: Acute myelogenous leukemia: A human cell line responsive to colony stimulating activity. Science 200: 1153, 1978.

91) Anderson LC, et al: Induction of erythroid differentiation in the human leukemia cell line K562. Nature 278: 364, 1979.

92) Koeffler HP and Golde DW: Human myeloid leukemia cell line. Blood 56: 344, 1980.

93) Thomas ED, et al: Marrow transplantation for acute nonlymphoblastic leukemia in first remission. New Eng J Med 301: 597, 1979.

94) Thomas ED: Bone marrow transplantation in acute leukemia. 18th Int Congress Hematology, Montreal, 1980.

95) Schaefer UW and Dicke KA: Preservation of haemopoietic stem cells. Transplantation potential and CFU-C activity of frozen marrow tested in mice, monkey and man. Cryoconservation des cellules normales et neoplastiques. Colloque Inserm, Villejuif, 1975, p 63.

96)*佐々木唀樹，他：上卜骨䯣細胞凍結保存の血 液幹細胞に与える髟響. 日血会誌 $42 ： 414$, 1979.

97) Whang J, et al: The distribution of the Philadelphia chromosome in patients with chronic myelogenous leukemia. Blood 22: $664,1963$.

98) Golde DW, et al: The Philadelphia chromosome in human macrophages. Blood 49:367, 1977.

99) Fialkow PJ, et al: Chronic myelocytic leukemia. Origin of some lymphocytes from leukemic stem cells. J Clin Invest 62: 815, 1978.

100) McCaffrey $R$, et al: Terminal deoxynucleotidyl transferase activity in human leukemic cells and in normal human thymocytes. New Eng J Med 292: 775, 1975.

101)* Sakamoto S, et al: Enzyme markers and cellular origin of human leukemia. Acta Haemat Jap 42: 918, 1979.

102) Janossy G, et al: Blast crisis of chronic myeloid leukemia. II. Cell surface marker analysis of lymphoid and myeloid cases. Brit J Hacmatol 34: 179, 1976.

103) Hoffbrand AV, et al: Biochemical markers in leukemia and lymphoma. In Strategies in
Clinical Hematology, Gross R, Hellriegel KP, Eds, Springer-Verlag, New York, 1979, p 25.

104) Bollum FJ: Terminal deoxynucleotidyl transferase: Biological studies. In Advances in Enzymology. Meister A, Ed, Vol 47, Wiley, New York, 1978, p 347.

105) Goldman JM, et al: In vitro colony-forming cells and colony stimulating factor in chronic granulocytic leukemia. Brit J Cancer 30: 1, 1974.

106) Moberg C, et al: Granulopoiesis in chronic myeloid leukemia. I. In vitro cloning of blood and bone marrow cells in agar culture. Scand J Haemat 12: 381, 1974.

107)*满口秀昭, 他: 造血幹細胞.内野治人, 柴田昭 編；慢性骨䯣性白血病，医歯薬出版，東京， 1979, p 72.

108) Singer JW, et al: Chronic myelocytic leukemia(CML): Failure to detect residual normal committed stem cells in vitro. Blood 53: 264, 1979.

109) Smalley RV, et al: Chronic granulocytic leukemia: Cytogenetic conversion of the bone marrow with cycle-specific chemotherapy. Blood 50: 107, 1977.

110) Cunningham I, et al: Result of treatment of $\mathrm{Ph}^{+}$chronic myelogenous leukemia with an intensive treatment regimen (L-5 protocol). Blood 53: 375, 1979.

111) Sharp JG, et al: Karyotypic conversion in $\mathrm{Ph}^{1}$-positive chronic myeloid leukemia with combination chemotherapy. Lancet 1: 1370, 1979.

112) Jacobson RJ, et al: Agnogenic myeloid metaplasia: A clonal proliferation of hematopoietic stem cells with secondary myelofibrosis. Blood 51: 189, 1978.

113) Chervenick PA; Increase in circulating stem cells in patients with myelofibrosis. Blood 41 : 67, 1973.

114) Antoniades $\mathrm{HN}$ and Scher CD: Radioimmunaassay of a human growth factor for Balb/ c-3T3 cells: Derivation from platelets. Pro Natl Acad Sci 74: 1973, 1977.

115) Ross R, et al: A platelet-dependent serum factor that stimulates the proliferation of arterial smooth muscle cells in vitro. Proc Natl Acad Sci 71 : 1207, 1974.

116) Castro-Malaspina $\mathrm{H}$, et al: Effects of blood and marrow cells from normal donors and patients with myeloproliferative disorders in marrow fibroblast growth. 18th Int Congress 
Hematology, Montreal, 1980.

117)*片山陖夫，他 : Chronic myelomonocytic leukemia と考えられる症例のコロニー形成能。 第22回臨床血液学会総会, 東京, 1980 .

118) Patt HM, et al: Cyclic neutropoiesis in grey collie dogs: A stem-cell problem. Blood 42: 873, 1973.

119) Golde DW and Cline MJ: Regulation of granulopoiesis. New Eng J Med 291: 1388, 1974.

120) Dale DC and Goaw RG Jr: Transplantation of allogenic bone marrow in caine cyclic neutropenia. Science 183: 83, 1974.

121) Moore MAS, et al: Monocyte production of colony stimulating factor in familial cyclic neutropenia. Brit J Haemat 27: 47, 1974.

122) Greenberg PL and Schrier SL: Granulopoiesis in neutropenic disorders. Blood 41:753, 1973.

123)* Mizoguchi $\mathrm{H}$, et al: Colony-forming cells in culture and colony-stimulating activity of the urine and the serum in a case of cyclic neutropenia. Tohoku J exp Med 119: 317, 1976.
124) Unitz U and Sachs L: Normal granulocyte colony-forming cells in the bone marrow of Yemenite Jews with genetic neutropenia. Blood 41: 745, 1973.

125) L'Esperance $P$, et al: Congenital neutropenia: In vitro growth of colonies mimicking the disease. Proc Natl Acad Sci 70: 669, 1973.

126) Asano $S$, et al: Demonstration of granulopoietic factor(s) in the plasma of nude mice transplanted with a human lung cancer and in the tumor tissue. Blood 49: 845, 1977.

127) Kimura N, et al: An established lung cancer cell line producing colony-stimulating activity. Proc Japan Acad Sci 54B: 548, 1968.

128)* Suda $T$, et al: A case of lung cancer associated with granulocytosis and production of the colony stimulating activity from the tumor. Brit J Cancer 41: 980, 1980.

129) Vainchenker $W$, et al: Megakaryocyte colony formation from human bone marrow precursors. Blood 54: 940, 1979.

*印は著者のグループの仕事である。 